\title{
超軌道速度再突入カプセル前方衝撃波層の数值解析*1 Numerical Analysis of Shock Layer in Front of a Super Orbital-Velocity Reentry Capsule
}

\author{
村 上 桂 一*2 ・藤 原 俊 隆*2 \\ Keiichi Murakami and Toshi Fujiwara
}

Key Words : High Enthalpy Flow, CFD, Vibrational Excitation

\begin{abstract}
The calculation code originally developed for a hypersonic nonequilibrium flow is applied to the flowfield in front of a super orbital-velocity reentry capsule. The re-entry speed is assumed to be $12 \mathrm{~km} / \mathrm{sec}$. The governing equations for a chemically and thermally nonequilibrium flow consist of the full Navier-Stokes equations, including the $11 \mathrm{chemical}$ species mass conservation equations and the vibrational-electronic energy conservation equation. The Park's two-temperature model is used for the chemical reaction rates. A Harten-Yee type upwind TVD scheme is used to solve the governing equations with a fractional step method. A semi-implicit scheme is introduced because of the stiffness of chemical source terms. Under a super orbital-velocity re-entry conditions, the results of numerical calculations indicate that the vibrational excitation behind a strong bow shock is prevented by nitrogen molecule dissociation. The obtained distributions of vibrational and translational temperatures and species mass fractions are essentially sufficient to yield not only the convective but also the radiative heat transfer to the capsule surface using the existing NEQAIR code.
\end{abstract}

\section{1.はじめに}

小惑星探㚗計画 (MUSES-C) 提案書1)によると,サン プルの回収を行うカプセルは約 $12 \mathrm{~km} / \mathrm{sec} の$ 超軌道速度 で地球大気に再突入する予定である．カプセルの設計に は, 空力加熱・輻射加熱量の推算, 飛行解析, 機体空力設 計, 熱防御システムなど様々な要素技術が必要になる、本 研究では特に熱防御システムに着目する，小惑星探查計画 提案書”ては最大加熱率を $13 \mathrm{MW} / \mathrm{m}^{2}$ と見積もり，耐熱 方法としてアブレーション法を採用している.アブレータ ーには熱伝達遮断効果があるため，実際にアブレーターを 通過して流入する熱伝達量と外部環境で決まる熱伝達量は 異なる. 従って，流入効率 $\alpha=($ 実際にアブレーターを通 過して流入する熱伝達量)/(外部加ら加えられる熱伝達量) を決めることにより，アブレーションによる熱遮断効果を 見積もることができる.これまでの耐熱設計に用いられて きた熱謤境は，弫点における実験的推算式から導かれた， いわば第一近似であり, 実際の現象は複雑で, カプセル周 りの流れ場は気体の熱化学的構造と密接に関連している. 従って再突入カプセルの熱環境を正確に予測するために は,カプセル周りの流れ場, 特に, 熱化学的構造の理解が 必要不可欠である。さらに超軌道速度再突入環境下におい ては，カプセル或いはアプレーターに外部から加えられる 熱伝達は, 対流熱伝達に加えて重撃波層からの輻射エネル ギーが重要となる，ある時刻における輻射エネルギーの算

\footnotetext{
*1 平成 11 年 7 月 29 日原稿受理

*2 名古屋大学大学院工学研究科航空宇宙工学尃攻物理気体力学講 座
}

出には，NEQAIR ${ }^{2\rangle}$ などの解析コードを用いることがで きるが, 入力値として各格子点での振動・並進温度, 各化 学種のモル分率が必要である。

そこで本研究では，超軌道速度再突入カプセル周りの熱 空気力学を CFDにより正確に把握する第一段階として, 熱伝達算出に必要な振動・並進温度及び各化学種の分布を 求めたい.

超軌道速度再突入の場合，再突入物体周囲の流れ場は極 めて高温になり, カプセル寸法が小さいので, 高度によっ ては弓状衝撃波後方で解離・電離する高温気体が, 熱的に も化学的にも非平衡状態のまま広い領域にわたって分布す ると予想される。そこで, Parkの 2 温度 11 化学種モデ ル3)を用い, 通常のナヴィエ・ストークス（N-S）方程式 に, 各化学種の質量保存式と振動・電子エネルギー保存式 を加えて支配方程式とする4．この支配方程式をTVD ス キームらにより数值解析して, 熱的・化学的非平衡流の並 進・回転と振動・電子温度分布及び各化学種の分布が得ら れる。

数値計算には，独自に作成した計算コードが用いられて いる.このコードは，别墖文 ${ }^{(6)}$ に報告されているように， 計算コストを抑えるための計算領域分割及びパラメータ設 定の簡略化, 計算安定化のための時間分割法，そして生成 項の硬直性に対処するための Semi-Implicit Scheme を導 入している。

\section{2. 計 算 方 法}

2.1 支配方程式と化学反応モデル 現時点で, 輻射熱 伝達と層流対流熱伝達を正しく与えるような輻射流体力学 
の数值計算を，再突入カプセル全機周りで 3 次元的に行う には, 計算コストが掛かり過ぎるだけでなく, 現実に必要 であるかどうかも定かではない，衝撃波と物体間で気体に よる輻射吸収が実際に存在しても，吸収しない、いわゆる 光学的に薄い気体を仮定した結果は安全側である．従っ て，カプセル表面での輻射熱伝達を見積もるために必要な 振動・電子温度分布などを, 輻射とカップリングしない流 体の方程式を解くことによって求めることにする．支配方 程式は，外力と輻射を無視したN-S 方程式に各化学種覧 量と振動・電子エネルギー保存式を組み込んだ円筒座標系 $(z, r)$ における軸対称流の方程式であり，これらを一般座 標系 $(\xi, \eta)$ に変換し，更に上流の物理量で無次元化する. ベクトル形で支配方程式を記述すると次式となる：

$$
\frac{\partial \hat{\boldsymbol{U}}}{\partial t}+\frac{\partial \hat{\boldsymbol{F}}}{\partial \boldsymbol{\xi}}+\frac{\partial \hat{\boldsymbol{G}}}{\partial \eta}=\frac{1}{R e}\left[\frac{\partial \hat{\boldsymbol{F}}_{v}}{\partial \hat{\xi}}+\frac{\partial \hat{\boldsymbol{G}}_{v}}{\partial \eta}\right]+\hat{\boldsymbol{S}}+\hat{\boldsymbol{H}} \text {. (1) }
$$

ここで $\hat{U}$ は保存量べクトル， $\hat{F} と \hat{G}$ は対流項ベクトル， $\hat{\boldsymbol{F}}_{v}$ と $\hat{\boldsymbol{G}}_{v}$ は粘性・熱伝導・㹡散項を成分に持つベクトル， $\hat{\boldsymbol{S}}$ は生成項ベクトル， $\hat{\boldsymbol{H}}$ は円筒座標系使用の結果生じる ベクトルである，各ベクトル成分の詳細は別報6を参照さ れたい.

2 温度モデルは，並進温度と回転温度が等しく，振動温 度と電子温度が等しいと仮定し、振動エネルギーと電子エ ネルギーの保存式をまとめて振動・電子エネルギーの保存 式4)と考えている，2 温度モデルにおける粘性係数, 熱伝 導係数，拡散係数の計算にはYosの式7)が用いられてい $3^{4)}$.

解離・電離反応を含む流れ場を計算するために, 11 化 学種 $\left(\mathrm{N}_{2}, \mathrm{O}_{2}, \mathrm{~N}, \mathrm{O}, \mathrm{NO}, \mathrm{O}_{2}^{+}, \mathrm{N}_{2}^{+}, \mathrm{N}^{+}, \mathrm{O}^{+}, \mathrm{NO}^{+}, \mathrm{e}^{-}\right)$を考慮 したParkの 17 反応モデルがが用いられる.

2.2 数值計算法 独自に作成した数值計算用コードで は, 式(1)左辺の対流項の計算に, Harten-Yee の NonMUSCL-type second-order upwind TVD scheme $e^{5)}$ が用い られている。これは，将来において再循環領域を含む再突 入物体後流を，風上差分法を用いて，精度良くしかも安定 に解くことを目標にしているためである。セル境界の物理 量の計算には，Liu-Vinokurの一般化されたRoe平均8) が用いられた，別報6で報告されたように，等温壁条件下 の計算など, 必要に応じて計算領域を分割し, エントロピ 一補正係数の設定を簡略化することで計算コストを抑える ことができる．粘性項などの式 (1) 右辺の空間微分は中心
差分で行う。

更に，解が収束する過程での衝撃波の移動に対処するた めに，時間分割法 (Fractional-Step Method) ${ }^{9)}$ を用いて， 式(2)のように各座標方向の時間積分を半分に分割して女 定化を図っている：

$$
\hat{U}_{j, k}^{n+1}=\mathcal{L}_{\epsilon}^{\Delta t / 2} \mathcal{L}_{\eta}^{\Delta t / 2} \mathcal{L}_{U}^{\Delta t} \mathcal{L}_{\eta}^{\Delta t / 2} \mathcal{L}_{\xi}^{\Delta t / 2} \hat{U}_{j, k}^{n}
$$

ここで, $\mathcal{L}_{\xi}^{\Delta t / 2}$ と $\mathcal{L}_{\eta}^{\Delta t / 2}$ は $\xi, \eta$ 方向へ $\Delta t / 2$ だけ進むという 意味の演算子, $\mathcal{L}_{v}^{\Delta t}$ は粘性項と生成項を計算する演算子て ある，超軌道速度再突入条件下で現奏的なタイムステップ で計算するために，振動・電子エネルギー保存式の生成項 にも，各化学種の生成項と同様に生成項のみを陰的に报う

Semi-Implicit Scheme 導入する.

流れ場を求める数值解析は次の手順で行っている：

Step 1. 化学反応無しで比熱比一定の完全気体に対し流れ 場を求める。

Step 2．これを初期条件として，2 温度，解離・電離化学 反応流を解く。

2.3 計算プログラムの妥当性 本研究のために独自に 作成した 2 温度・11 化学種, 熱的・化学的非平衡流数值 解析コードの变当性を調べるたに，第 13 回航空機計算 空気力学シンポジウムに招けるワークショップ課題 II OREX Case 2 課題番号II-2 で与えられた条件で計算を行 った. II-2 の計算条件を第 1 表に示し, ワークショップ に提出された計算結果 ${ }^{10)}$ を第 2 表に示す。第 2 表では， 本計算に用いたコート゚による結果をPresentとして示し ている、ワークショップに提出した古い結果11に比べ, 熱流束の最大值が約 2 倍になった．これは，等温壁条件で 計算する場合に，流束制限関数に境界值を与えるようにコ ードを修正したためである．また，振動・電子温度の最大 值が低下したが、古い計算では分子解離による振動エネル ギー減少が考慮されていなかったためである。

第 2 表から，各計算の対流熱伝達が平均值に対しファク ター1.3 以内であるので，工学的なオーダー評価の観点か らこれらの計算結果は妥当であると考えると，本研究のた

第 1 表 OREX ワークショップ課題II-2 の計算条件

\begin{tabular}{cccccc}
\hline 課題番号 & $\begin{array}{c}\text { 上流速度 } \\
U_{\infty} \\
{[\mathrm{m} / \mathrm{s}]}\end{array}$ & $\begin{array}{c}\text { 上流温度 } \\
T_{\infty} \\
{[\mathrm{K}]}\end{array}$ & $\begin{array}{c}\text { 上流圧力 } \\
p_{\infty} \\
{\left[\mathrm{N} / \mathrm{m}^{2}\right]}\end{array}$ & $\begin{array}{c}\text { 壁温 } \\
T_{\text {wall }} \\
{[\mathrm{K}]}\end{array}$ & 流体モデル \\
\hline $\mathrm{II}-2$ & 5.562 & 248.1 & 23.60 & 1,519 & $\begin{array}{l}\text { 層流, 非平衡, } \\
\text { 非蝶壁 }\end{array}$ \\
\hline
\end{tabular}

\begin{tabular}{|c|c|c|c|c|c|}
\hline ID & Applicant name & Organization & $\begin{array}{c}\dot{Q}_{\max } \\
{\left[\mathrm{MW} / \mathrm{m}^{2}\right]}\end{array}$ & $\begin{array}{l}T_{\max } \\
{[\mathrm{K}]}\end{array}$ & $\begin{array}{c}T_{Y \max } \\
{[\mathrm{K}]}\end{array}$ \\
\hline H-3 & T. Kurotaki & $\begin{array}{l}\text { Mitsubishi } \\
\text { Electric Co. }\end{array}$ & 0.290 & 13,224 & - \\
\hline H-5 & $\begin{array}{l}\text { K. Murakami, T. Fujiwara } \\
\text { and S. Nakano (Old) }\end{array}$ & Nagoya Univ. & 0.182 & 9.719 & 8,529 \\
\hline $\mathrm{H}-8$ & Y. Yamamoto & NAL & 0.338 & 9,065 & - \\
\hline $\mathrm{H} \cdot 9$ & $\begin{array}{l}\text { N. Nagatomo, S. Kano, } \\
\text { S. Yamamoto and H. Daiguji }\end{array}$ & Tohoku Univ. & 0.412 & 12,275 & - \\
\hline $\mathrm{H} \cdot 10$ & $\begin{array}{l}\text { T. Shimada, N. Tamura } \\
\text { and N. Sekino }\end{array}$ & Nissan Motor & 0.452 & 9,836 & - \\
\hline- & K. Murakami (Present) & Nagoya Univ. & 0.336 & 11,906 & 7,369 \\
\hline
\end{tabular}

第 2 表 OREX ワークショップ課題II-2 の計算結果 
めに作成したコード（Present）の使用により，熱的・化 学的非平衡流の妥当な数值解が得られると判断される.

\section{3. 計算結果と考察}

この計算コードを MUSES-C 再突入カプセル1)を模擬 した形状に適用し，（1）完全気体 (比熱比 $\gamma$ 一定) と（2）2 温度モデル 11 化学種解離・電離反応流について, 断熱・ 非触媒壁条件

$$
\frac{\partial T}{\partial n}=0, \quad \frac{\partial T_{v}}{\partial n}=0, \quad \frac{\partial Y_{s}}{\partial n}=0
$$

で計算された、ここで，nは壁に垂直方向であり，Ysは $s$ 化学種の質量分率である. 超軌道速度再突入条件として は高度 $60 \mathrm{~km}$, 速度 $12 \mathrm{~km} / \mathrm{sec}$ が設定された。

断熱壁条件を用いた理由は，本研究が第一段階として超 軌道速度再突入カプセル前方に生じる強い弓状衙擊波直後 の振動・電子温度励起に着目しており，カプセル壁面の条 件が影響しないと考えたからであり，最小格子間隔の観点 から等温壁条件の計算に比べ計算コストの少ない断熱壁条 件を用いた. 更に，本計算で用いた断熱条件は特別な条件 であることに注意されたい，すなわち，非触媒壁を仮定し 2 温度モデルを用いる場合，次式で表される壁面熱流束：

$$
\left(\lambda_{\text {tr }}+\lambda_{\text {rot }}\right) \frac{\partial T}{\partial n}+\left(\lambda_{\text {vlb }}+\lambda_{e}\right) \frac{\partial T_{v}}{\partial n}
$$

が 0 となるように, 振動エネルギーに対する壁面適応係数 がゼロであるという仮定で，壁面での振動・電子温度勾配 及び並進・回転温度勾配が 0 という断熱壁条件を設定して いる.ここで, 熱伝導係数 $\lambda$ の添え字 tr, rot, vib, e は, 並進, 回転, 振動, 電子熱伝導係数であることを表 寸.

計算格子が第 1 図に示される. 対称軸は格子間の中央に 位置し，反射条件が用いられている．断熱壁条件なので， 物体表面付近の最小格子間隔 $\Delta y_{\min }=100 \mu \mathrm{m}$ と比較的大 きくし，格子点数は $\xi \times \eta=71 \times 101$ となった。なお，物 体表面付近の最小格子幅は,

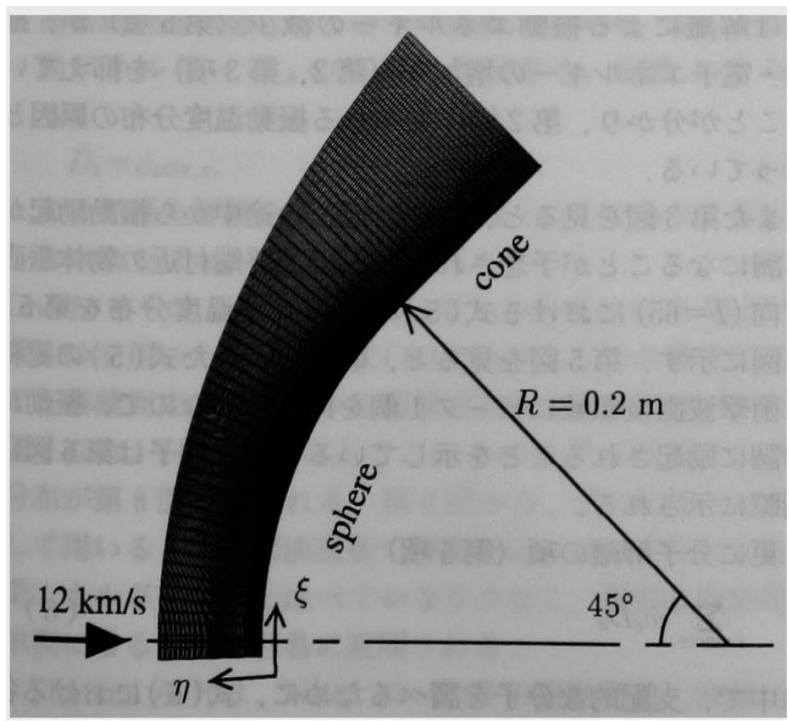

第 1 図 MUSES-C 再突入カプセル前方領域の計算格子

$$
\Delta y_{\min }<\frac{0.1}{\sqrt{R e}}=211 \mu \mathrm{m}
$$

を满たしており，冨流境界層厚さの 1/50以下に設定され ている ${ }^{12)}$. 等温壁条件で壁面への熱流束を計算する場合 は， $\Delta y_{\operatorname{m} \ln }$ を更に小さくする必要があることに注意してお く.

対称軸に最も近い位置で表面に垂直方向（ $\xi$ 方向の位置 $I=3 に お け る \eta$ 方向）の温度分布が第 2 図に示される。

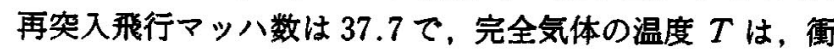
撃波直後で70,000 K を超えている。計算結果から得られ た衝撃波離脱距離は，比熱比一定と見なせる低マッハ数実 験値から作られた Billig の経験式 ${ }^{13)}$

$$
\frac{\delta_{\mathrm{B}}}{R}=0.143 \exp \left[3.24 / M_{\infty}^{2}\right] \text { for sphere cone }
$$

に， $M_{\infty}=37.7$ と再突入カプセルのノーズ半径 $R=0.200$ $\mathrm{m}$ を代入した值 $\delta_{\mathrm{B}}=0.0287 \mathrm{~m}$ と一致している(第 2 図).

2 温度モデル解離・電離反応を考慮すると, 吸熱反応の ため衝撃波離脱距離が半分近くに減少した．衝撃波直後で 並進・回転モードは完全励起され，並進・回転比熱は温度 によらないと仮定している゙ので，並進・回転温度 $T$ の 最大值は完全気体の場合に近い值を示している.

第 2 図で振動・電子温度 $T_{V}$ の分布を見ると, 振動・電 子励起は 2 段階上昇を示している. 第 3 図の等振動・電子 温度線図を見ると，瑖点近傍では衝撃波面と物体表面の中 央て等高線が密になっており, それが 2 段目の励起を表し ているので，2段階励起が起きている領域が sphere と coneのつなぎ目あたりまで伸びていることが分かる.

上流值で無次元化した支配方程式の振動・電子ェネルギ 一式の生成項は，次式で与えられている：

$$
\begin{aligned}
& \underbrace{-p_{e}\left(\frac{\partial u}{\partial z}+\frac{\partial v}{\partial r}\right)}_{1}+\underbrace{\rho_{s} \frac{e_{v, s}^{*}-e_{v, s}}{\left\langle\tau_{s}\right\rangle}}_{s=\text { mole. }} \\
& \underbrace{+3 \beta_{1} \rho_{e}\left(T-T_{v}\right) \sum_{s=1}^{10} \frac{\nu_{e, s}}{M_{s}}}_{2} \\
& \underbrace{-\sum_{s=8}^{9} \dot{n}_{e, s} \hat{I}_{s}}_{i} \underbrace{+\sum_{s=\text { mole. }} \dot{w}_{s} \hat{D}_{s}}_{s} .
\end{aligned}
$$

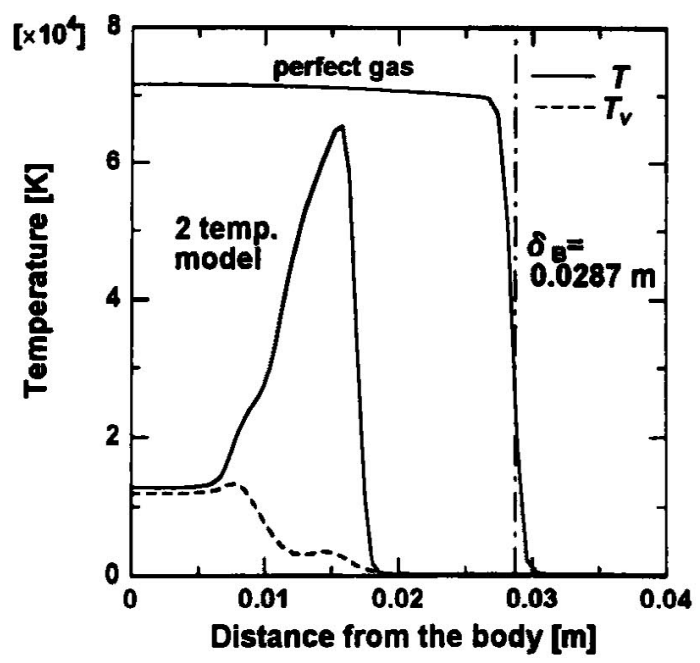

第 2 図 対称軸に隣接したライン $(I=3)$ 上の温度分布 


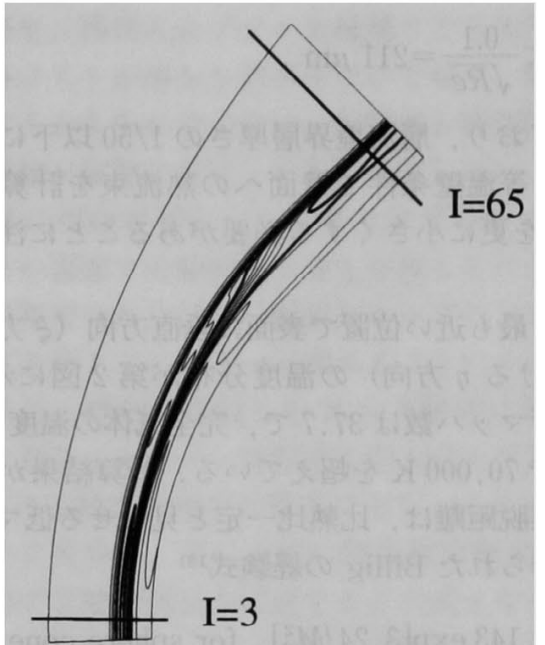

第 3 図 再突入カプセル前方の等振動温度線図

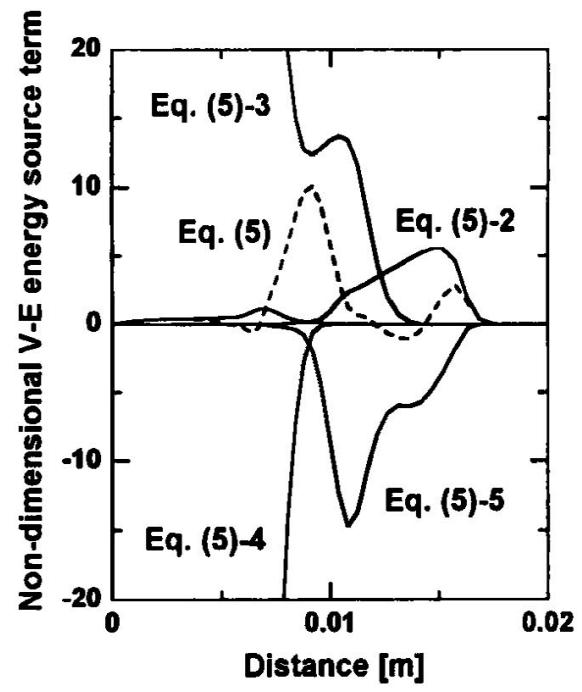

第 4 図 式( 5 )の各項の $I=3$ ライン上分布

ここで第 1 項は電子圧力 $p_{e}$ が行う仕事の項である. 第 2 項は振動・電子と並進・回転間の緅和項で， $e_{v, s}^{*}, e_{v, s}$ は $T, T$ Vで見積もった振動エネルギーを表しており，振動 緩和時間にはP Park の修正式 (4)〈福〉が用いられている。 第 3 項は電子-分子衝突の緩和項て,$\beta_{1}$ は振動・電子エネ ルギー生成項を無次元支配方程式 (1) に合わせて無次元化 した結果生じる係数, $\nu_{e, s}$ は電子と他の化学種との衝突頻 度, $M_{\delta}$ は化学種 $s$ の分子量である。第 4 項は化学反応に よる電子エネルギー生成項で, 用いられた Park モデルに おいては次の化学反応 $\left(s=\mathrm{O}^{+}, \mathrm{N}^{+}\right)$を考慮している:

$$
\begin{aligned}
& \mathrm{O}+\mathrm{e}^{-} \longleftrightarrow \mathrm{O}^{+}+\mathrm{e}^{-}+\mathrm{e}^{-}, \\
& \mathrm{N}+\mathrm{e}^{-} \longleftrightarrow \mathrm{N}^{+}+\mathrm{e}^{-}+\mathrm{e}^{-} .
\end{aligned}
$$

すなわち，化学種 $s$ の電子衝突電離反応速度 $\dot{n}_{e, s}$ とその 1 価電離エネルギー $\hat{I}_{s}$ にって, 電子衝突電離による電子 エネルギー損失を表している，第 5 項は 2 原子分子とその イオンの再結合・解離による振動エネルギー変化を，化学 種 (分子) $s$ の解離反応速度 $\dot{w}_{s}$ と平均振動エネルギー $\hat{D}_{s}$ で表しており，再突入物体前方では解離によって負にな

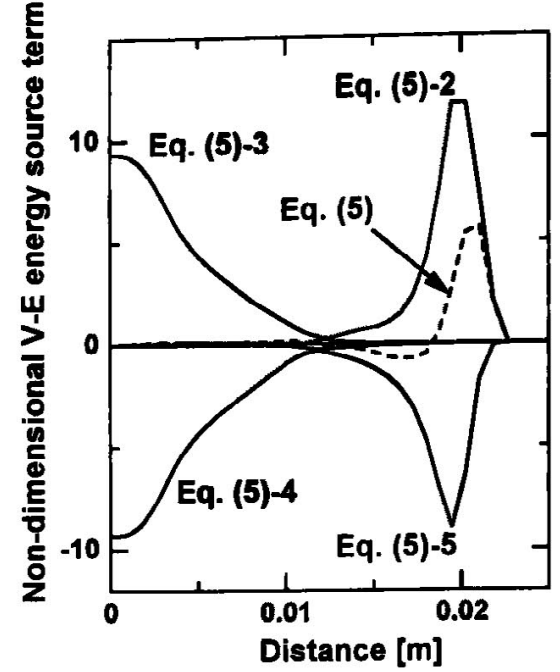

第 5 図 式( 5 )の各項の $I=65$ ライン上分布

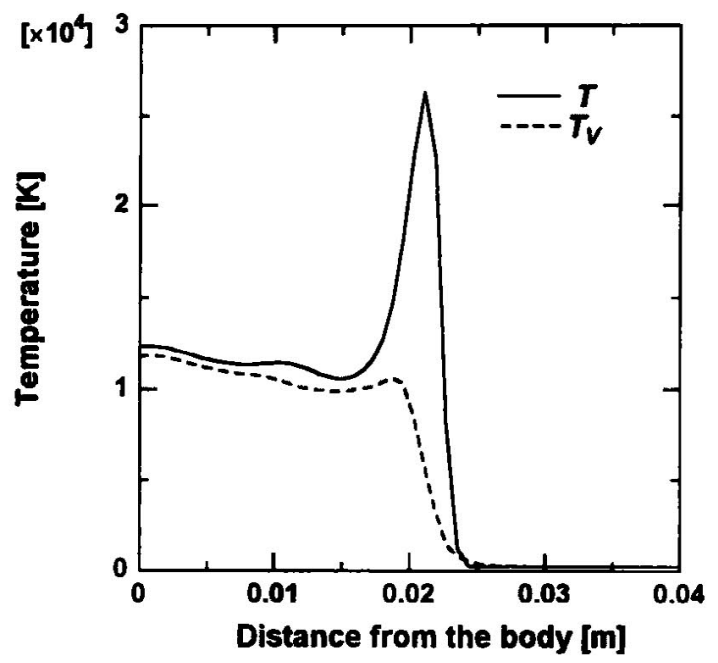

第 6 図 $I=65$ ライン上の並進・振動温度分布

る. $I=3$ 位置におけるこれら 5 項の分布が第 4 図に示さ れる.破線は全項の総和を示し，第 1 項は他の項に比へて 小さいので省略されている．第 4 図から、衝撃波直後領域 では解離による振動エネルギーの減少 (第 5 項)が，振 動・電子エネルギーの増加率（第 2, 第 3 項）を抑えてい ることが分かり，第 2 図に見られる振動温度分布の原因と なっている.

また第 3 図を見ると，物体円錐部の途中から振動励起が 単調になることが予想される. 円錐部終端付近の物体垂直 方向 $(I=65)$ における式 $(5)$ の各項及び温度分布を第 5 ， 6 図に示す．第 5 図を見ると，破線で示した式(5)の総和 は衝擊波直後領域にピーク 1 個を持つだけなので, 振動が 単調に励起されることを示している。そその様子は第 6 図に 明暸に示される。

更に分子解離の項（第 5 項）

$$
\sum_{s=\text { mole. }} \dot{w}_{s} \hat{D}_{s}
$$

の中で，支配的な分子を調へるために，式（6)における各 分子の $I=3$ ライン上分布が第 7 図に示される. 第 7 図か 


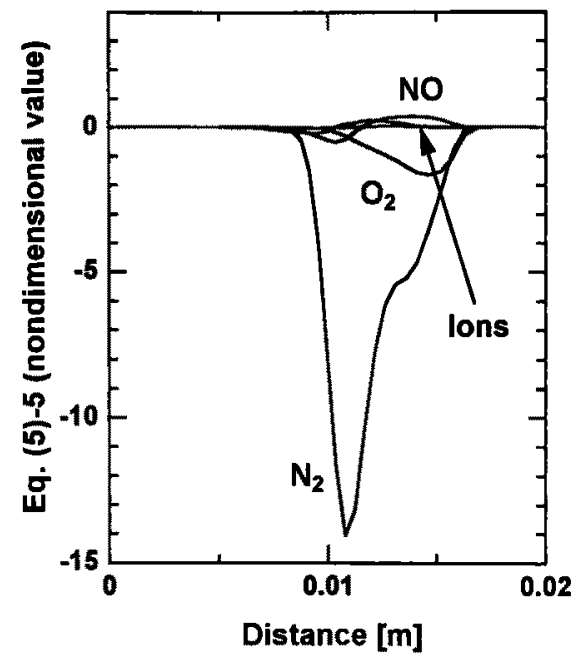

第 7 図 $I=3$ ライン上の分子・分子イオンの振動エネルギー 生成項の無次元值

ら，振動励起の抑制には窒素分子の解離が支配的であるこ とが分かる。

式(6)の $\bar{D}_{s} は$, 変化率 $\dot{w}_{s}$ で生成または消隇する 2 原 子分子の単位質量当りの振動エネルギーを表しており，い くつかのモデルが提案されている：この值の取り方が振動 温度分布に大きく影響する。

高振動励起状態にある分子が優先的に解離すると仮定し

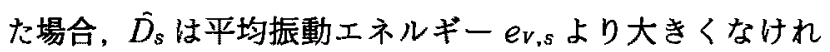
ばならないことを考慮し，次の 3 通りの与え方が考えられ ろ.

・高振動励起状態にある分子の振動エネルギーが, 分子の 解離エネルギー $\tilde{D}_{s}$ の何割程度かを仮定する：

$$
\hat{D}_{s}=c_{1} \tilde{D}_{s}, \quad 0<c_{1}<1 .
$$

- Park の提案によれば, 解離によって失われる振動エネ ルギーは解離エネルギーと平均並進エネルギーのレベル 差に等しい:

$$
\tilde{D}_{s}=\tilde{D}_{s}-k T \text {, }
$$

ここで $k$ はボルツマン定数である.

・高振動励起状態にある分子の振動エネルギーが, 平均振 動エネルギー $e_{V, s}$ の何倍かを仮定し, 定数 $c_{2}$ で与え る:

$$
\hat{D}_{s}=c_{2} e_{V, s}
$$

ここで優先解離を仮定するならば $c_{2}>1$ であり，仮定し ないならば $c_{2}=1$ である。

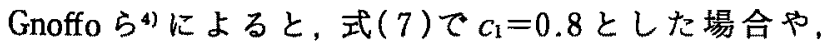
式（8）を用いた場合は, 式（9）で $c_{2}=1$ とした場合に比べ て，解離反応が起きている衝撃波值後で振動温度がかなり 低くなる. $I=3$ ライン上でこれらのモデルの $\bar{D}_{s}\left(s=\mathrm{N}_{2}\right)$ 分布が第 8 図に示される. 第 8 図から, 式(9)を $c_{2}=1$ と して用いると, 衝撃波直後で解離反応によって失われる振 動エネルギーが他と比べてかなり少なく，振動温度励起が 単調になることが容易に証明される。

Sharma ら ${ }^{15)}$ は， $\mathrm{N}_{2}$ について 57 の振動状態と解離状態 間での遷移速度を考慮してマスター方程式を解き, ポピュ

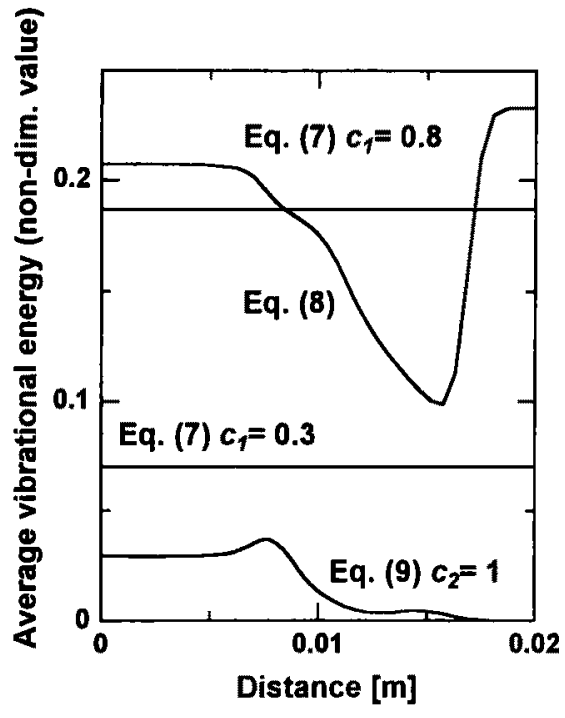

第 8 図 $I=3$ ライン上の $\hat{D}_{s}\left(s=\mathrm{N}_{2}\right)$ の分布

レーション分布を求め, 解離速度定数と解離によって除去 される平均振動エネルギーを計算した。その結果，Park の 2 温度モデル（幾何平均）で計算した解離速度定数は計 算結果と比較してオーダー1の範囲内にあり，平均振動工 ネルギーは解離エネルギー $\bar{D}_{s}$ の約 $30 \%$ となった。

本計算の場合, 上述のように窒素分子解離が支配的なの で, 式(7)に打ける全分子に対して $c_{1}=0.3$ と置き， $\dot{w}_{s}$ はParkの 2 温度モデルを用いて計算された。

$$
\text { 4. ま と め }
$$

高度 $60 \mathrm{~km}$, 速度 $12 \mathrm{~km} / \mathrm{sec} の$ 超軌道速度再突入条件 で断熱壁を仮定した場合の，再突入カプセル形状前方にお ける熱的・化学的非平衡流について, N-S 方程式と各化 学種, 振動・電子エネルギー保存式を, Parkの 2 温度・ 11 化学種モデルを用いて数值的に解き，並進・回転及び 振動・電子温度分布が得られた. 数值計算に用いた計算コ 一ドは独自に作成されたもので，対流項の計算にTVD ス キームを用い, 時間分割法と Semi-Implicit Scheme を導 入して計算の安定化が図られている。

計算結果から，MUSES-Cの様な超軌道速度再突入条 件では, 物体前方の広い領域で, 弓状衝撃波後方での振動 温度励起が窒素分子の解離によって抑制されることが分か った。

こうして得られた再突入物体周囲の並進・回転及び振 動・電子温度分布と化学種の分布から, NEQAIR ${ }^{2}$ 等の プログラムを用いて，輻射熱伝達を算出することができ る.

\section{参考 献}

1）宇宙科学研究所小惑星探査ワーキンググループ：小惑星探査計 画 (MUSES-C) 提案書, 1995.

2) Park, C.: Nonequilibrium Air Radiation (NEQAIR) Program: User's Manual, NASA TM 86707, 1985.

3) Park, C.: Assessment of Two-Temperature Kinetic Model for Ionizing Air, J. Thermophysics Heat Transfer, 3 (1989) 
pp. 233-244

4) Gnoffo, P. A., Gupta, R. N. and Shinn, J. L.: Conservation Equations and Physical Models for Hypersonic Air Flows in Thermal and Chemical Nonequilibrium, NASA TP-2867, 1989.

5) Yee, H. C. : A Class of High Resolution Explicit and Implicit Shock Capturing Methods, NASA Technical Memorandum 101088, 1989.

6）村上桂一，藤原俊隆：極超音速 TVD スキームにおけるエントロ ピー補正係数設定の効率化，日本航空宇宙学会論文集, 48 (2000), pp. $61-66$.

7) Yos, J. M.: Transport Properties of Nitrogen, Hydrogen, Oxygen, and Air to 30,000 K, Tech. Memo. RAD-TM-637 (Contract AF 33(616)-7578), AVCO Corp., Wilmington, Massachusetts, 1963.

8) Liu, Y. and Vinokur, M.: Upwind Algorithms for General Thermo-Chemical Nonequilibrium Flows, AIAA Paper 89 0201, 1989.

9) Strang, G. : Linear Algebra and Its Applications, Academic
Press, New York, 1976.

10) 山本行光: 実験結果解説及び資料, 第 13 回航空機計算空気力学 シンポジウム論文集, 1995 , pp. 198-379.

11) Murakami, K., Fujiwara, T. and Nakano, S.: High Enthalpy Workshop Problem II OREX, 第 13 回航空機計算空気力学シシ ポジウム論文集, $1995, \mathrm{pp} .128-133$.

12）藤井孝藏：流体力学の数値計算法，東京大学出版会，東京，1994 pp. $174-180$.

13) Billig, F. S. : Shock-Wave Shapes around Spherical- and Cylindrical-Nosed Bodies, J. Spacecraft Rockets, 5 (1968), pp. 1247-1248.

14) Park, C.: Problems of Rate Chemistry in the Flight Regimes of Aeroassisted Orbital Transfer Vehicles, Thermal Design of Aeroassisted Orbital Transfer Vehicles, Nelson, H. F., ed., Progr. Astronaut. Aeronaut., 96 (1985), pp. 511-537.

15) Sharma, S. P., Huo, W. and Park, C.: The Rate Parameters for Coupled Vibration-Dissociation in Generalized SSH Approximation, AIAA-88-2714, 1988. 